\title{
UJI KANDUNGAN KIMIA DAN CEMARAN LOGAM KERANG KIMA (Tridacna sp.) KERING YANG DIPERDAGANGKAN DI KABUPATEN KONAWE UTARA SULAWESI TENGGARA
}

\author{
Test of Chemical Content and Metal Contamination of Dry Clam (Tridacna sp.) Traded in North Konawe Regency \\ Southeast Sulawesi
}

\author{
Samsul Alam*, Kobajashi T. Isamu, Suwarjoyowirayatno \\ Jurusan Teknologi Hasil Perikanan, Fakultas Perikanan dan Ilmu Kelautan Universitas Halu Oleo, Kendari, \\ Sulawesi Tenggara, Indonesia
}

*Email korespondensi: samsulalam240796@gmail.com (Telp: +6282195310932)

Diterima: 14 Agustus/ Disetujui 30 Oktober 2020

Cara sitasi: Alam S, Isamu KT, Suwarjoyowirayatno. 2020. Uji kandungan kimia dan cemaran logam kerang kima (Tridacna sp.) kering yang diperdagangkan di Kabupaten Konawe Utara Sulawesi Tenggara. Jurnal Fish Protech. 3(2):194-199.

\begin{abstract}
The aim of this study was to determine the characteristics of chemical composition (water, ash, protein, fat, and carbohydrate) and Metal Contamination of Dry Clam. Analysis of the data used in this study is to usedescriptive analysis. The results of the analysis of the chemical content of the highest treatment of water content are found in P2 with a value of $25.84 \%$. The highest ash content was found in the $P 2$ treatment with a value of $13.84 \%$. The highest level of protein treatment was at $P 3$ with a value of $14.28 \%$. The highest treatment fat content was in $P 3$ with a value of $2.43 \%$ and the highest treatment carbohydrate content was in $P 2$ with a value of $1.88 \%$ and. The results of the analysis of heavy metals were the highest $C d$ levels were at $P 3$ with a value of $0.074 \mathrm{mg} / \mathrm{Kg}$ and the lowest was at $P 10.057 \mathrm{mg} / \mathrm{Kg}$ and the highest $P b$ metal at $P 30.026 \mathrm{mg} / \mathrm{Kg}$ the lowest was at $P 10.016 \mathrm{mg} / \mathrm{Kg}$.
\end{abstract}

Keywords: Clam (Tridacna sp.), Chemical content, Heavy metals

\section{ABSTRAK}

Tujuan penelitian ini adalah untuk mengetahui karakteristik komposisi kimiawi (air, abu, protein, lemak, dan karbohidrat) dan cemaran Logam berat pada Kerang kima Kering. Analisis data yang digunakan dalam penelitian ini adalah menggunakan analisis deskriptif. Hasil analisis kadar kimia perlakuan kadar air tertinggi terdapat pada P2 dengan nilai $25,84 \%$. Kadar abu tertinggi terdapat pada perlakuan P2 dengan nilai $13,84 \%$. Perlakuan protein tertinggi terdapat pada P3 dengan nilai 14,28\%. Kadar lemak perlakuan tertinggi terdapat pada P3 dengan nilai 2,43\% dan kadar karbohidrat perlakuan tertinggi terdapat pada P2 dengan nilai $1,88 \%$ dan. Hasil analisis logam berat kadar $\mathrm{Cd}$ tertinggi pada P3 dengan nilai 0,074 mg / Kg dan terendah pada P1 0,057 mg / Kg dan logam Pb tertinggi pada P3 0,026 mg / $\mathrm{Kg}$, terendah pada P1. 0,016 mg / Kg.

Kata kunci Kerang kima (Tridacna sp.) kering, Kandungan Kimia, Logam berat

\section{PENDAHULUAN}

Potensi sumber daya hayati untuk perikanan tangkap Sulawesi Tenggara diperkirakan mencapai 250.000 ton per tahun. Dari angka tersebut, jumlah tangkap pada tahun 2015 mencapai $66,58 \%$, yang meliputi jenis-jenis ikan yang bernilai ekonomi tinggi seperti tongkol, tuna, kerapu, nepoleon dan hasil tangkap lainnya meliputi udang, kepiting, cumi serta beberapa jenis kerang-kerangan (BPS Provinsi Sulawesi Tenggara 2015). Kabupaten Konawe Utara mengandalkan sub sektor perikanan sebagai salah 
satu sumber pertumbuhan ekonomi utama. Sektor pertanian (termasuk perikanan) menyumbang PDRB (produk domestik regional bruto) sebesar $42,82 \%$ pada tahun 2014, dengan laju pertumbuhan riil PDRB sebesar $8 \%$. Sumbangsih sub sektor perikanan merupakan yang terbesar dalam sektor pertanian, yaitu mencapai $39,62 \%$. PDRB perikanan atas dasar harga berlaku di Kabupaten Konawe Utara mencapai Rp. 413.083,97 juta pada tahun 2014 atau sekitar $16,96 \%$ dari total PDRB, dengan laju pertumbuhan PDRB atas dasar harga berlaku sebesar $10,01 \%$. Produksi Perikanan Kabupaten Konawe Utara pada Tahun 2014 dalam hal ini produksi kerang mencapai 117,9 ton. Pada tahun 2018 produksi dan Nilai hasil perikanan Kabupaten Konawe Utara yang meliputi ikan, cumi-cumi, udang, kerang dan lain-lain mencapai 4536,1 ton (BPS Kabupaten Konawe Utara, 2018).

Salah satu jenis biota dalam kelompok moluska adalah kerang kima (Setyawan, 2013). Kima termasuk dalam kelas Palecypoda (Bivalvia), kelompok hewan bertulang lunak yang dilindungi sepasang cangkang bertangkup. Bernapas dengan insang yang berbentuk seperti lembaran yang berlapis-lapis. Kima berukuran besar dan berumur panjang yakni \pm 8 tahun. Kima merupakan salah satu jenis kerang-kerangan yang memiliki protein yang cukup tinggi. Braley et al. (1992) melaporkan bahwa kandungan protein dan lipid $T$. gigas remaja umur tujuh bulan bervariasi sesuai kondisi pertumbuhan dan berkisar antar 26,6-34,5\% dan $5,1-7,3 \%$ dari berat kering jaringan masingmasing.

Populasi kima di alam telah menurun drastis yang terutama diakibatkan oleh pengambilan ilegal, penyakit dan parasit, predator, faktor lingkungan dan faktor antropogenik (Ambariyanto, 2007). Pencemaran yang dapat ditimbulkan oleh limbah ada berbagai macam bentuk. Pencemaran berupa bau, warna, bahkan pemutusan mata rantai dari suatu tatanan lingkungan hidup atau organisme yang ada, tingkat akhirnya akan menghancurkan tatanan ekosistemnya. Pencemaran tersebut biasanya berasal dari limbah kimia. Senyawa kimia yang sangat beracun bagi organisme hidup dan manusia adalah yang mempunyai bahan aktif dari logam-logam berat.

Penelitian Kadar Logam Berat Timbal $(\mathrm{Pb})$ yang dilakukan (Karneli, 2010) pada otot kerang kima sisik (Tridacna squamosa) dibeberapa perairan pelabuhan feri Bira kabupaten Bulukumba diperoleh hasil tertinggi $0,00105 \mathrm{mg} / \mathrm{kg}$. Menurut organisasi kesehatan dunia (World Health Organization) atau WHO yang menyatakan bahwa batas ambang logam timbal pada otot kerang-kerangan dan hewan laut yang masih dapat dikomsumsi yaitu kecil dari 0,715 $\mathrm{mg} / \mathrm{kg}$.

\section{METODE PENELITIAN}

\section{Alat dan Bahan}

Alat yang digunakan pada penelitian alat yang digunakan untuk alat untuk analisis kimia meliputi: tabung reaksi (Iwaki), spektrofotometer UV-VIS (Shimadzu), vortex (Ika), timbangan analitik (Iwaki), hot-plate, gelas piala, gelas ukur, batang pengaduk, pipet tetes, pipet mikro (Dragonlab micropipette), corong, tabung reaksi, labu takar, erlenmeyer (Pyrex), dan alat destilasi (Pyrex). Alat untuk analisis logam berat meliputi: vandorn water sample, botol contoh plastik polyetilen $250 \mathrm{ml}$ dan $500 \mathrm{ml}$, turbidimeter (hach), coolbox (Ocean), oven (Memmert), kantong plastik, transek kuadrat, breaker glass (Duran), tabung erlemeyer (Iwaki), corong gelas, labu takar (RRT), pipet, kertas label, suntikan (Axion), pinset, freezer (GEA), baki plastik, dan timbangan digital (Sonic SSA1000), Spektofotometer Serapan Atom (SSA).

Bahan baku yang digunakan pada penelitian adalah sampel kerang kima kering. Bahan analisis yang digunakan yaitu aquades, $\mathrm{HNO}_{3}, \mathrm{HCLO} 4$, serbuk $\mathrm{Ca}(\mathrm{NO} 3) 2$, $\mathrm{NaNO} 3$, dan $\mathrm{PO}^{3}{ }_{-}^{-}$, asam nitrat (HNO3) pekat, asam klorida $(\mathrm{HCl})$ pekat, dan aquaregia (larutan yang dibuat dari percampuran asam klorida pekat dan asam nitrat pekat ).

\section{Metode Pengambilan Sampel}

Metode yang digunakan pada penelitian ini yaitu metode pengambilan sampel acak sederhana (Simple 
Random Sampling) disertai wawancara. Pengambilan sampel yang dilakukan dari beberapa pedagang yang ada di Desa Bandaeha (S1), Desa Mataiwoi (S2), dan Desa Laimeo (S3) tiap sampel yang diambil sebanyak $50 \mathrm{gr}$ dan kemudian dibawa di Laboratorium untuk dilakukan pengujian

\section{Parameter uji}

Analisis uji kimia meliputi kadar air, kadar abu, kadar protein, kadar lemak dan kadar karbohidrat dan analisis kandungan logam berat ( $\mathrm{Cd}$ dan $\mathrm{Pb})$.

\section{Analisis Data}

Analisis data penelitian ini menggunakan analisis deskriptif. Analisis deskriptif pada penelitian ini digunakan untuk memberikan gambaran umum tentang data yang telah diperoleh.

\section{HASIL DAN PEMBAHASAN}

Berdasarkan hasil penelitian tentang analisis uji kimia kerang kima kering yang dipasarkan di Kabupaten Konawe Utara Sulawesi Tenggara dapat dilihat pada Tabel 1.

Tabel 1. Analisis uji kimia

\begin{tabular}{llllll}
\hline \multirow{2}{*}{ Kode sampel } & \multicolumn{5}{c}{ Hasil uji } \\
\cline { 2 - 6 } & $\begin{array}{c}\text { Kadar air } \\
(\%)\end{array}$ & $\begin{array}{l}\text { Kadar abu } \\
(\%)\end{array}$ & $\begin{array}{l}\text { Kadar } \\
\text { protein } \\
(\%)\end{array}$ & $\begin{array}{l}\text { Kadar } \\
\text { lemak } \\
(\%)\end{array}$ & $\begin{array}{l}\text { Kadar } \\
\text { karbohidrat } \\
(\%)\end{array}$ \\
\hline P1 & 24,19 & 12,06 & 12,63 & 1,04 & 1,18 \\
P2 & 25,84 & 13,84 & 13,39 & 0,51 & 1,88 \\
P3 & 24,73 & 13,52 & 14,28 & 2,43 & 1,23 \\
\hline
\end{tabular}

Keterangan: $\mathrm{P} 1$ = Pedagang Desa Bandaeha, $\mathrm{P} 2$ = Pedagang Desa Mataiwoi, P3 = Pedagang Desa Laimeo

Berdasarkan hasil penelitian tentang analisis logam berat kerang kima kering yang dipasarkan di Kabupaten Konawe Utara Sulawesi Tenggara dapat dilihat pada Tabel 2.

Tabel 2. Analisis logam berat

\begin{tabular}{lccc}
\hline \multirow{2}{*}{ Parameter } & \multicolumn{3}{c}{ Kode sampel } \\
\cline { 2 - 4 } & $\mathrm{P} 1$ & $\mathrm{P} 2$ & $\mathrm{P} 3$ \\
\hline Kadmium $(\mathrm{mg} / \mathrm{kg})$ & 0,057 & 0,061 & 0,074 \\
Timbal $\quad(\mathrm{mg} / \mathrm{kg})$ & 0,016 & 0,019 & 0,026
\end{tabular}

Keterangan : P1 = Pedagang Desa Bandaeha, P2 = Pedagang Desa Mataiwoi,

\section{P3 = Pedagang Desa Laimeo}

\section{Uji Kimia}

\section{Kadar Air}

Hasil uji kadar air kerang kima (Tabel 1) menunjukkan nilai tertinggi terdapat pada $\mathrm{P} 2$ dengan nilai $25,84 \%$ dan nilai terendah pada P1 24,19\% . Hasil tersebut berbeda jauh dengan penelitian Baria et al. (1987) tentang kandungan kimia T. squmosa yang melaporkan kadar air masing-masing 74,5-78,9\% dan penelitian Bhara et al.(2018) yang melaporkan kadar air pada T. maksima yaitu 77,32\%. Perbedaan kadar air yang diperoleh kerena sampel telah dilakuan proses pengolahan yaitu proses pengeringan pada kerang kima sebelum dipasarkan. Dalam hal ini akanterjadi perubahan kadar air apabila telah dilakukan proses pengolahan, serta Semakin tinggi suhu dan lamanya waktu pengeringan yang diberikan, akan memberikan pengaruh yang sangat besar terhadap kecepatan perpindahan air. 
Wirakartakusumah (1992) pengeringan merupakan operasi pengurangan kadar air bahan padat sampai batas tertentu sehingga bahan tersebut bebas terhadap serangan mikroorganisme, enzim, dan insekta yang merusak.

\section{Kadar abu}

Berdasarkan (Tabel 1) hasil analisis kadar abu yang didapatkan berkisar antara 13,84-12,06\% hasil tersebut tidak berbeda jauh dengan penelitian Baria et al. (1987) tentang kandungan kimia T. squmosa yang melaporkan kadar abu masing-masing 8,4\% dan $16,7 \%$. Hasil analisis kadar abu yang didapatkan tergolong tinggi yang dimana standar kadar abu yang ditetapkan oleh BSN (1992) yaitu maksimum 1,6\%. Tingginya nilai kadar abu yang diperoleh diduga karena lokasi habitat kerang kima mengandung mineral yang cukup tinggi. Menurut Winarno (2008) semakin tinggi kadar abu dapat menunjukkan bahwa suatu bahan tersebut juga memiliki kandungan mineral yang tinggi. Sudarmadji (2003) kadar abu dengan jumlah yang sangat tinggi pada bahan pangan menandakan kualitas bahan pangan yang kurang baik, meskipun kadar abu dalam bahan pangan tetap dibutuhkan dengan kadar yang dianjurkan.

\section{Kadar protein}

Hasil uji proksimat terhadap kadar protein kerang kima yang dipasarkan di Kabupaten Konawe Utara (Tabel 1) menunjukkan nilai rerata tertinggi terdapat pada P3 dengan nilai $14,28 \%$ sedangkan nilai terendah pada P1 dengan nilai $12,63 \%$. Nilai tersebut tidak berbeda signifikan dengan penelitian Lucas (1994) yang melaporkan kadar protein kerang kima segar $13,53-13,89 \%$. Hal ini diduga karena proses pengeringan bahan baku mengunakan sinar matahari dan hanya memaksimalkan suhu sinar matahari, sehingga tidak terjadi penguapan air yang terlalu besar pada daging kerang kima yang dapat menyebabkan denaturasi protein. Rendahnya nilai kadar protein pada kerang kima diduga karena lama proses pengeringan dan pada saat aktivitas perdagangan bahan baku terus terpapar oleh matahari dengan tujuan agar bahan baku tetap kering dan dapat bertahan cukup lama

\section{Kadar lemak}

Hasil uji proksimat terhadap kadar lemak kerang kima yang dipasarkan di Kabupaten Konawe Utara (Tabel. 1) menunjukkan nilai rerata tertinggi terdapat pada P3 dengan nilai $2,43 \%$ dan nilai terendah pada P2 dengan nilai $0,51 \%$. Nilai tersebut tidak berbeda signifikan dengan penelitian Lucas (1994) yang menyatakan kadar lemak pada kerang kima masing-masing 0,34-1,34\%. Perbedaan nilai kadar lemak pada P3 dan P2 diduga adanya perbedaan lama proses pengeringan pada saat pengolahan dan seringnya bahan baku terpapar sinar matahari pada saat diperdagangkan. Menurut Prangdimurti (2007), tingkat kerusakan lemak bervariasi tergantung suhu yang digunakan dan waktu pengolahan, semakin tinggi suhu yang digunakan maka kerusakan lemak akan semakin meningkat.

\section{Kadar karbohidrat}

Hasil uji proksimat terhadap kadar karbohidrat kerang kima yang dipasarkan di Kabupaten Konawe Utara (Tabel 1) menunjukkan rerata nilai tertinggi terdapat pada P2 dengan nilai 1,88\% dan untuk nilai terendah terdapat pada P1 dengan nilai 1,18. Hasil tersebut berbeda dengan penelitian Lucas (1994) yang menyatakan kadar karbohidrat pada kerang kima masing-masing 0,21-3,68. Hal tersebut diduga karena bahan baku telah dilakukan proses pengolahan yaitu proses pengeringan.

\section{Analisis logam berat \\ Cd (Kadmium)}

Berdasarkan hasil uji kadar logam berat $\mathrm{Cd}$ pada kerang kima yang diperdagangkan di Kabupaten Konawe Utara (Tabel 2) menunjukkan rerata nilai tertinggi terdapat pada sampel P2 dengan nilai 0,074 $\mathrm{mg} / \mathrm{kg}$ dan nilai terendah terdapat pada P1 dengan nilai $0,057 \mathrm{mg} / \mathrm{kg}$. Hasil penelitian ini memperlihatka bahwa logam berat kadmium pada kerang kima belum melewati baku mutu yang ditetapkan oleh pemerintah (BPOM, 2009) dan (SNI, 2009) yang mensyaratkan agar konsentrasi kadmium pada bahan makanan maksimum 1,0 mg/kg. Tingginya nilai $\mathrm{Cd}$ pada $\mathrm{P} 2$ dibanding dengan P1 dan P3 diduga karena lokasi penjualan yang berada di pinggir jalan, dimana aktifitas lalu lintas begitu lancar sehingga polusi-polusi dari kendaraan yang mungkin mengandung logam $\mathrm{Cd}$

http://ojs.uho.ac.id/index.php/jfp 
dapat terkontaminasi pada kerang kima yang diperdagangkan.

\section{$\mathrm{Pb}$ (Timbal)}

Berdasarkan hasil uji kadar logam berat $\mathrm{Pb}$ pada kerang kima yang diperdagangkan di Kabupaten Konawe Utara (Tabel 2) menunjukkan rerata nilai tertinggi terdapat pada sampel P2 dengan nilai 0,026 $\mathrm{mg} / \mathrm{kg}$ dan nilai terendah terdapat pada $\mathrm{P} 1$ dengan nilai $0,016 \mathrm{mg} / \mathrm{kg}$. Hasil tersebut lebih tinggi dibandingkan penelitian Karneli (2010) menyatakan

\section{KESIMPULAN}

Berdasarkan hasil dan pembahasan, maka dapat disimpulkan sebagai berikut:

1. Hasil uji proksimat dengan nilai tertinggi pada kadar air P2 25,84\%, kadar abu P2 13,84\%, kadar protein P3 14,28\%, kadar lemak P3 2,43\% dan kadar karbohidrat P2 1,88\%, sedangkan untuk nilai terendah pada kadar air P1 24,19\%, kadar kadar logam Pb kima sisik (Tridacna squamosa) dibeberapa perairan pelabuhan feri Bira kabupaten Bulukumba diperoleh hasil tertinggi $0,00105 \mathrm{mg} / \mathrm{kg}$. Tingginya nilai tersebut diduga karena adanya kegiatan penambangan di teluk lasolo yang mencemari perairan. Berdasarkan standar SNI (2009) menyatakan batas maksimum logam Timbal (Pb)yaitu 1,5 mg/gr. Dalam hal ini kerang kima yang diperdagangkan ditiga Kecamatan di Kabupaten Konawe Utara masih aman untuk di konsumsi.

abu P112,06\%, kadar protein P1 12,63\%, kadar lemak $\mathrm{P} 2 \mathrm{0,51 \%}$ dan kadar karbohidrat $\mathrm{P} 1 \mathrm{1,18 \%}$.

2. Hasil analisis logam berat pada kerang kima terdapat perbedaan nilai dari tiap sampel. Kadar logam $\mathrm{Cd}$ dengan rerata nilai 0,026-0,016 mg/kg dan kadar logam $\mathrm{Pb}$ dengan rerata nilai 0,074$0,057 \mathrm{mg} / \mathrm{kg}$. Hasil tersebut masih memenuhi standar logam berat pada bahan pangan yang di tetapkan, dalam hal ini produk tersebut masih aman untuk dikonsumsi.

\section{DAFTAR PUSTAKA}

Ambariyanto., 2007. Pengelolaan Kima di Indonesia: Menuju Budidaya Berbasis Konservasi, Jurnal IImu Kelautan. 17(1):13-17

Association of Official Analytical Chemist [AOAC]. 2005. Official Methods of Analysis (18 Edn). Association of Official Analytical Chemist Inc. Mayland. USA.

Badan Standarisasi Nasional. 2009. Standar Nasional Indonesia (SNI) 7388:2009 tentang Batas Maksimum Cemaran Mikroba dalam Pangan. BSN:Jakarta (ID).

Baria, A. 1987. Aspect of the chemistry of giant clams. University of papua New Guenea, port Moresby.

Bhara, M, A. E, D, Meye. Y, Kamlasi. 2018. Analysis of bivalves nutrient content consumed in the coastal coast of arubara, ende : Jurnal Biotropikal Sains Vol. 15, No. 3 (Hal 38 - 48).

BPS Kabupaten Konawe Utara. 2018. Kabupaten Konawe Utara dalam Angka 2018.

BPS Provinsi Sulawesi Tenggara. 2015. Potensi Perikanan Sulawesi Tenggara.
Braley RD. 1992. The Giant Clams: A hatchery and nursey culture manual. ACIAR Monograph No. 15. Camberra. P: 144.

Karneli. 2010. Kandungan Logam Berat Timbal (Pb) Pada Kerang Kima Sisik (Tridacna Squamosa)[Skripsi]. Makassar: Fakultas Sains Dan Teknologi Universitas Islam Negeri Alauddin Makassar- Makassar.

Lucas, J.S. 1994. The biology, exploitation, and mariculture of giant clams (Tridacnidae).: Journal Rev. Fish. Sci., 2(3):181- 223.

Prangdimurti, E., F. R. Zakaria, Dan N. S. Palupi. 2007. Modul E-Learning EvaluasiNilai Gizi Biologis Pangan. Departemen IImu Dan Teknologi Pangan.Bogor :Fakultas Teknologi Pertanian IPB.

Qorimeifebria R. 2014. Keanekaragaman jenis dan distribusi Family Tridacnidae (Kerang Kima) di Perairan Pulau Karang Congkrak,Kepulauan Seribu [Skiripsi]. Jakarata: Fakultas Sains dan Teknologi Universitas Islam Negri Syarif Hidayatulah 
ISSN : 2621 - 1475

Setiawan, H. 2013. Ancaman Terhadap Populasi Kima (Tridacna sp.) dan Upaya Konservasinya di Taman Nasional Taka Bonerate. Balai Penelitian Kehutanan Makassar. Makassar.

Sudarmaji, S., B. Hariyono., dan Suhardi. 2003. Analisa Bahan Makanan dan Pertanian. Liberty. Yogyakarta. $171 \mathrm{hlm}$.
Winarno, F.G. 1995. Enzim Pangan. Penerbit PT. Gramedia Pustaka Utama. Jakarta.113 HIm.

Wirakartakusumah, A. (1992). Perlakuan dan Unit Proses Industri Pangan. Institut Pertanian Bogor. 